\title{
Information Warfare Within the Context of Cybernetic Epistemology
}

\author{
D.V. Bindas \\ Moscow State Institute of International Relations (MGIMO) \\ 76, Prospect Vernadskogo, Moscow, Russian Federation, 119454
}

In the present article the author studies and reviews the essential scientific opinions and discourse on the understanding of the term and phenomena of Cybernetics. The article is the author's vision of the concept of cybernetic epistemology based on its progressive methodological features. The main idea of the understanding of the information warfare category as a complex social system (society) in the context of cybernetic epistemology is also developed in the present research. The concept of complexity theory has not yet been applied in the study of ontological characteristics of the "information warfare" phenomenon so far. This kind of analyzing method allows us to highlight the true essential characteristics of "information warfare". There are recursiveness and spontaneous nature among them. This kind of epistemology methods and their possible and proper application in Cybernetics were analyzed and reviewed in the present paper. Such an analyzing confirmed the relevance of this research for the formalization of the world's complex phenomena. It also determined the possibility of constructive generalization of knowledge and research data. However, this knowledge should be gained in the process of complex formalization of the studied phenomena characteristics (ontology) and the maximum permissible changes and transformation in their conditions and forms. theory

Keywords: cybernetic epistemology; information warfare; Cybernetics; complexity

\section{Article history:}

The article was submitted on 07.10.2019

The article was accepted on 14.01.2020

For citation: Bindas A.J. Information warfare within the context of cybernetic epistemology. RUDN Journal of Philosophy. 2020; 24 (2): 297-302. DOI: 10.22363/23132302-2020-24-2-297-302

The public relations arise in the information space in connection with the information itself. The development process of such relations requires a

C Bindas A.J., 2019

This work is licensed under a Creative Commons Attribution 4.0 International License https://creativecommons.org/licenses/by/4.0/ 
comprehensive assessment, which would go beyond a highly specialized methodology of a particular field of knowledge. A comprehensive study of the civilizational, "cultural, socioeconomic, and political" [1] aspects of phenomena appearing in society should be carried out in the set of methods and algorithms relevant to different fields of knowledge.

One of the phenomena of information civilization became information warfare. Its methodology is at the intersection of sociological and humanistic disciplines and natural sciences. The definition of information warfare became the subject of researches for physics, philosophers, political scientists since the second half of the $\mathrm{XX}$ century. It seems reasonable to consider information warfare as a complex social system. This system exists in the information and "cognitive development theory" [2], which explains the formation of behavioral patterns of the society and behavioral urges of the individual.

The object of this study is a complex interdisciplinary phenomenon. And as a consequence, it has a complex method of implementation in public relations in the post-global world. By analogy with the Big Bang theory, information warfare is the directed influence of information quanta. They form and "influence public opinion" [3] and each person value system. Because of the interdisciplinary nature of the phenomenon, the method of scientific knowledge applicable in the study information warfare should consist of the different fields of knowledge methodology. And in conjunction, they constitute the object of research.

Cybernetic epistemology is one of the dominant methods that can most comprehensively describe the ontological characteristics and the nature of "information war". In our opinion, cybernetic epistemology in this context is an overlooked area in the scientific literature. To eliminate this defect, this article is devoted to cybernetic epistemology as a method of scientific knowledge and, in particular, to ontological characteristics of information warfare. In this regard, it seems necessary to define Cybernetics first of all.

The term "Cybernetics", "the study of principles governing goal-directed, selfregulating systems" [4], has been used since the time of Ancient Greece, referring to the art of controlling the ship, in Plato's "Laws", and later to the art of management as a political phenomenon in Andre-Marie Ampere's "Experience of the philosophy of Sciences". However, the development of Cybernetics as science begins in the XX century in 1948 with the work "Cybernetics, or control and communication in the animal and the machine" [5] by Norbert Wiener. In his research, $\mathrm{N}$. Wiener draws parallels in the processes of transmission, storage, and processing of information in mechanisms and living organisms. He defines Cybernetics itself as "control and communication in the animal and the machine." D. Lidov mentioned that "we should recognize cybernetics as adequate to describe the role of information in primitive forms" of living organisms [6].

Two years later, in 1950, "Cybernetics and society", another work by $\mathrm{N}$. Wiener, was released. It examines the general laws of social institutions and automatic systems functioning. The cybernetics theory "was especially influential 
from the 1950s to the early 1970s" [7]. Thus, in the second half of the XX century, the interdisciplinary nature of Cybernetics has been determined. Besides, the necessity of convergence of the results of social and natural Sciences dealing with the management and processing of information has been first elaborated.

In 1955, three years before the official translation of $\mathrm{N}$. Wiener's works into Russian, the Soviet mathematician S.L. Sobolev in collaboration with A.A. Lyapunov and A.I. Kitov, published "the Main features of Cybernetics" [8] in the journal "Questions of philosophy". Accordingly, soviet scientists opened up new areas for research in the Soviet scientific community. Later A.N. Kolmogorov, doctor of physical and mathematical Sciences, defined Cybernetics as "a scientific direction that studies machines, living organisms and their associations solely from the point of view of their ability to perceive certain information, store this information in memory, transmit it through communication channels and process it into signals directing their activities in the appropriate direction" [9]. Such an understanding of Cybernetics differs from N. Wiener's s view only in the issue of allocating Cybernetics as an independent science.

To our mind, the most inclusive definition A.G. Butkovsky gave: "Cybernetics is a synthetic science of management, information, and systems" [10]. Nevertheless, it seems reasonable to define Cybernetics as a science that has a complex synthetic character, due to the constructive generalization in such form as laws of the phenomena of life sciences, artificial science, and social sciences, as well as the normative definition of their existing models. Cybernetics theory "provide insight into systems that are too complex to predict their future" [11] and , "as a way of thinking, changes how we act" [12].

Turning to the cybernetic epistemology as a method of scientific knowledge issue, it is necessary to define the term "epistemology". Thus, epistemology is a branch of philosophy that studies the problems of cognition and the connection between knowledge and reality, it is a new approach to understanding of the nature of humanitarian and social knowledge [13]. It characterizes not all the features of the cognitive process, but only those that show "positive attributes to form a true representation of reality" [14]. M.V. Fedorov defines epistemology as "the science of epistemes, which is a common space of knowledge and a method of fixing the "order of being", and also relations between "words" and "things" hidden from immediate observation. On its basis the codes of perception, practice, and knowledge are built, separate ideas and concepts are generated" [15]. The focus of epistemological research is due to the role of the subject of knowledge as an observer, who fixes in his mind certain autonomous facts which are beyond his influence.

The convergence of epistemology and Cybernetics creates a fundament for the study of phenomena and objects of the world based on their metric and topological essence. In this case, the metric characterizes the distance between the elements of the system. This distance can be indicated numerically in the physical and mathematical sciences or can be expressed in certain comparability of the properties 
of phenomena, for example, the ability or inability of the material to conduct heat. Topology determines the constant of the studied object in its development. It is necessary for fixing the unchanging characteristics of the subject of research. "In other words, the topology in complex social systems follows the changes in the productive forces, production relations, and superstructure. And it should fix their state, when it is possible to say, that, for example, the capitalist socio-economic formation without "breaks" and "gluing" is although highly deformed, but still old" [15].

At the same time, metric and topology, in our opinion, should be used in cybernetic epistemology to simplify the processing of an array of information and search for analogies in the studied processes of different fields of knowledge. The formalization of a complex phenomenon opens up opportunities for the scientific community to analyze and further to apply the identified patterns of existence and functioning of complex systems. It seems reasonable to determine the content of cybernetic epistemology as a method of scientific knowledge through a constructive generalization of knowledge obtained as a result of complex formalization of the characteristics of the studied phenomena and the maximum permissible changes in their states.

Information warfare is an example of a complex social system. In our opinion, it can be seen in the context of cybernetic epistemology. It is worth noting that "the complexity [of the system] is not in the quantitative diversity of the elements of the system, but in the qualitative self-creative (autopoietic) and recursive behavior of the complex system" [15]. For example, a spiral historical sense of war and the existence of the sixth and seventh generation wars [16] defines the cyclical processes of the opponent' $s$ influence on each other. That is why it is right to talk about "information war" recursiveness. Another ontological characteristic of information warfare is its autopoietic behavior. It is proved that "for 5,5 thousand years existence of human civilization, there were over 15 thousand armed conflicts in which approximately 3,5 billion people died" [17]. The globalization process and the emergence of post-modern States together with sovereign countries has created an array of possible subjects of geopolitical information warfare. The accelerated development of programs for methods of conducting contactless wars based on existing "historical and cultural backgrounds" [18] and experience makes the information war a phenomenon of spontaneous nature for an indefinite period. Together with the potential for self-reproduction of its subjects it characterizes the information war as a complex social system. Therefore, is possible to define information war as a subject of cybernetic epistemology research, metrically defined as a type of directed contactless war. It happens under the influence of charged information quanta, topologically used to achieve a radical result, which forms imperatives and regulators of social relations.

Taking into account all the above said we conclude:

Firstly, Cybernetics is a science that has a complex synthetic character, due to the constructive generalization in the form of laws and regularities of the 
phenomena of life science, artificial science, and social sciences, as well as the normative definition of models of their existence.

Secondly, we define the content of cybernetic epistemology through a constructive generalization of knowledge obtained as a result of a complex formalization of the characteristics of the studied phenomena and the maximum permissible changes in their states.

Thirdly, information war as a subject of cybernetic epistemology research is metrically defined as a type of directed contactless war. It is influenced by the charged information quanta topologically applied to achieve a radical result, which forms imperatives and regulators of social relations.

\section{References}

[1] Garrow EE, Hasenfeld Y. The Epistemological Challenges of Social Work Intervention Research. Research on Social Work Practice. 2017; 27 (4): 494-502.

[2] Shaw EM. Evaluating Knowing and Reasoning in College for Use in Christian Higher Education. Christian Educational Journal. 2019; 16 (2): 344-358.

[3] Dubois E, McKelvey F. Political bots: Disrupting Canada's democracy. Canadian Journal of Communication. 2019; 44 (2): 27-33.

[4] Wilf E. Separating noise from signal: The ethnomethodological uncanny as aesthetic pleasure in human-machine interaction in the United States. American Ethnologist. 2019; 46 (2): $202-213$.

[5] Wiener N. Cybernetics or Control and Communication in the Animal and the Machine. New York: The Technology Press and John Wiley \& Sons, Inc. Paris: Hermann et Cie, 1948. $223 \mathrm{p}$.

[6] Lidov D. Genuine Triadicity in Computation. Cognition and Consciousness. Chinese Semiotic Studies. 2019; 15 (2):175-197.

[7] Picon A. Cities and information systems: From the birth of modern urbanism to the emergence of the smart city. Flux. 2018; 111-112 (1-2): 80-93.

[8] Sobolev SL. Osnovnye cherty kibernetiki. SL Sobolev, AI Kitov and AA Lyapunov. Voprosy filosofii. 1955: (4): 136-148. (In Russian).

[9] Kolmogorov AN. Kibernetika. Bolshaya sovetskaya entsiklopediya. 2 ed. Vol. 51. Moscow; 1957. P. 149-151. (In Russian).

[10] Butkovskij AG. K metodologii i filosofii kibernetiki. Kratkie tezisy. Moscow; 2010. 80 p. (In Russian).

[11] Peters MA, Besley T. Critical philosophy of the postdigital. Review of Contemporary Philosophy. 2019; 18: 64-79.

[12] Chapman J. Living and Loving Cybernetics. World Futures. 2019; 75 (1-2): 92-100.

[13] Mikeshina LA. Epistemology in Russia: ITS formation in the context of social sciences and the humanities. Epistemology and Philosophy of Science. 2019; 56 (1): 8-22.

[14] Kondrashov VA. Novejshij filosofskij slovar'. VA Kondrashov, DA Chekalov and VN Koporullina. 3 ed. Moscow; 2008. 672 p. (In Russian).

[15] Fedorov MV. Kiberneticheskaya ehpistemologiya kak metodologicheskaya paradigma issledovaniya slozhnykh sotsial'nykh system. Istoriya i pedagogika estestvoznaniya. 2016; (1):14-17. (In Russian).

[16] Slipchenko VI. Vojny shestogo pokoleniya. Oruzhie $i$ voennoe iskusstvo budushhego. Moscow; 2002. P. 153. (In Russian).

[17] Kapitanets IM. Silnyj flot - silnaya Rossiya. Moscow; 2006. 544 p. (In Russian). 
[18] Máhrik T, Pavlíková M, Root J. Importance of the incarnation in the works of C.S. Lewis and S. Kierkegaard. European Journal of Science and Theology. 2018;14 (2): 43-53.

\title{
About the author:
}

Bindas D.V. — the applicant at the Department of Philosophy MGIMO (e-mail: dmitrij.bindas@bk.ru).

\section{Информационная война в контексте кибернетической эпистемологии}

\author{
Д.В. Биндас
}

Московский государственный институт международных отношений Проспект Вернадского, 76, Москва, Российская Федераџия, 119454

В статье автор приводит обзор ключевых научных мнений о понимании термина «кибернетика». В тексте статьи представлен авторский взгляд понятия кибернетической эпистемологии исходя из ее методологических особенностей. Получает развитие авторский взгляд на понятие информационной войны как сложной социальной системы в его исследовании в контексте кибернетической эпистемологии. Концепция теории сложности до настоящего момента не применялась в исследовании онтологических характеристик феномена «информационная война». Предложенное автором рассмотрение информационной войны в контексте теории сложности позволяет выделять такие сущностные его характеристики, как рекурсивность на неопределенном участке времени и самопроизвольный характер. Проведенный анализ методов эпистемологии, их возможного и должного применения в кибернетике подтвердил актуальность исследования для формализации сложных явлений окружающего мира, определил возможность конструктивного обобщения знания, полученного в результате комплексной формализации характеристик исследуемых явлений и предельно допустимых изменений их состояний.

Ключевые слова: кибернетическая эпистемология; информационная война; кибернетика; теория сложности

\section{История статьи:}

Статья поступила 07.10.2019

Статья принята к публикации 14.01.2020

Для цитирования: Биндас Д.В. Информационная война в контексте кибернетической эпистемологии // Вестник Российского университета дружбы народов. Серия: Философия. 2020. T. 24. No 2. С. 297-302. DOI: 10.22363/2313-2302-2020-24-2-297-302

\section{Сведения об авторе:}

Биндас Д.В. — соискатель кафедры философии МГИМО (e-mail: dmitrij.bindas@bk.ru). 